Efforts to protect the fauna, although increasing, are still inadequate. Protective legislation is widespread but not well enforced. The ten private or quasi-public conservation organisations, with impressive exceptions such as the Friends of English Harbor and the Barbados Natural Trust, are mostly only beginning to become influential.

The Carlozzis show that conservation of natural and historic features underlies the chief hope for economic survivial of these islands - tourism. The needs they foresee include research, educational guidance, strong conservationoriented institutions, physical planners, land acquisition, and expertise in site development. To pool efforts and to encourage both local and necessary outside support, they propose a Caribbean International Park System. If the mutual benefits can sufficiently attract these individualistic islands to such a scheme, other advantages are obvious.

F. H, WADSWORTH

\title{
Man and the California Condor by Ian McMillan. Dutton, New York,
} $\$ 5.95$.

The author is a rancher whose home is within the mountainous horseshoe of country which dips to within 20 or $\mathbf{3 0}$ miles of Los Angeles at the southern end and stretches two arms northward for 150 miles along either side of the San Joaquin Valley. This also is 'condor' country, and in 1963 he and two others were commissioned by the Audubon Society to report on the status of this immense vulture. The California condor Gymnogyps californianus had last been censused in the 1940's by Carl Koford who put the total stock at 60 ; McMillan estimated that it had dropped to 46 . He discusses the causes of this sharp decline in 20 years. First, in historical sequence, it was shot; then its eggs were collected. As these activities declined it began to suffer disturbance in its remote breeding places by the opening up of wilderness areas to tourism, or by burning off scrub to increase forage; after that poisons and finally pesticides. One does not gather that during the last 50 years it has been subject to exceptional pressures but its slow rate of reproduction due to the bird not breeding until about its sixth year and the laying of a single egg every other year makes it extremely sensitive to loss. The author comments on the rather dim attitude of the forest authorities, who are officially charged with the conservation of the condor, to their responsibilities, and ponders on the final irony of trapping condors for captive breeding in zoos.

The California condor can be saved in the wilderness: 'If man chooses to do so, and with no more than a token sacrifice, he can live with the condor.' The book is well illustrated with good photographs of condors and the country they live in.

G. DES FORGES

\section{Journey to Red Birds by Jan Lindblad. Collins, $36 s$.}

This is a pleasant, informal account of how the author visited Trinidad and Tobago, with side excursions to Bonaire and Brazil, and successfully filmed some of those islands' most remarkable and beautiful birds, especially the scarlet ibis and oilbirds of Trinidad. A good deal of varied natural history is mixed with the narrative, and there is an accompaniment of 24 excellent colour photographs and 26 black-and-white. But perhaps the most valuable point that the author makes is the urgent need for far more effective conservation of these and other striking, and in some cases unique, animals in a part of the world that is rapidly becoming over-congested, developed, and tourist-ridden. The scarlet ibis, Trinidad's national bird, has a breeding colony within sight of Port-ofSpain, and no other regular breeding colonies of this dazzling bird appear to be 
known anywhere (though breeding is presumably regular somewhere in the Orinoco river system). Yet the protection theoretically accorded to it is not fully effective; in some years poaching and disturbance can, and do, effectively prevent the birds from breeding at all. Jan Lindblad gives a vivid account of how he personally took a hand in improving the situation at least in one year; we must hope that the improvement lasts.

D. W. SNOW

\section{A Contribution to the Ornithology of Zambia by C. W. Benson and M. P. Stuart Irwin. OUP, 50s.}

In the course of preparation is a book, The Birds of Zambia, which will be the culmination of some 20 years' intensive study of the birds of Northern Rhodesia (now Zambia) by C. W. Benson, as well as elaborate follow-up and complete revision of a series of check lists of progressively increasing scope and value. This paper, published on behalf of the National Museums of Zambia, is an essential preliminary and supplement to that project, and its co-authors are unrivalled in their knowledge of ornithology in their respective territories either side of the Zambezi, besides both being indefatigable field workers. Though comprehensive on an individual basis, it is restricted to some 240 selected species and provides extensively important details which could not be conveniently included in the major work. It concentrates, too, mainly on western Zambia, and particularly Barotse, a region hitherto little documented, and besides including a wealth of additional information on distribution, ecology and breeding seasons, also discusses a variety of taxonomic problems. In conclusion, it is scarcely necessary to mention that it is of the high quality that one associates with the authors.

C. R. S. PITMAN

\section{History of the Birds of the Cape Verde Islands by David A. Bannerman and W. Mary Bannerman. Oliver \& Boyd, $£ 66 \mathrm{~s}$.}

When David Bannerman originally set out to write The Birds of the Atlantic Islands, of which this is volume IV, his declared intention was to do two volumes on the birds of the Canaries, Madeira and the Azores. The Canaries and Salvages volume appeared in 1963, but volume II he found necessary to split into two; in the third volume, on the Azores, he was helped by his wife, who has established an ornithological reputation in her own right. Now, again with her aid, he has added a fourth volume, to complete the oceanic islands in the tropical and subtropical parts of the north-eastern Atlantic. This maintains the high standards already set by the first three (two of which were reviewed in ORYX in April 1966 and December 1967), and contains much additional material of interest, going so far as to include an excellent chapter by Norman Riley, on the butterflies together with a colour plate. Indeed one third of the book's 458 pages is occupied by matter other than the normal systematic treatment. These additional delights include a fairly detailed account of the authors' journeys in the archipelago, and notes from the diary of the junior author. Some 34 birds are illustrated in fine colour plates by D. M. Reid-Henry and P. A. Clancy.

As with all oceanic islands the main interest of the Azores to the naturalist lies in the random selection of the avifauna of the nearest mainland which has both managed to reach them and succeeded in building up a viable population. They include two endemics, one of which, the Razo lark, has set taxonomists by the ears for many years in their attempts to determine its affinites - currently it has come to rest in Alauda, although Dr Bannerman is clearly not happy about the latest fashion. Some species notably the white-breasted cormorant, appear to have become extinct on the islands in recent years, but fortunately these do not 